\title{
UPAYA MENINGKATKAN HASIL BELAJAR MATEMATIKA SISWA KELAS VIII MELALUI PENDEKATAN KONSTRUKTIVISME PADA MATERI BANGUN RUANG SISI DATAR
}

\author{
${ }^{1}$ Dian Rapitasari, ${ }^{2}$ Dewi Herawaty, ${ }^{3}$ Nurul Astuty Yensy \\ ${ }^{1,2,3}$ Program Studi Pendidikan Matematika JPMIPA FKIP Universitas Bengkulu \\ email :'drapitasari@gmail.com, ${ }^{2}$ dewiherawaty71@gmail.com, ${ }^{3}$ nurulastutyyensy@yahoo.com
}

\begin{abstract}
Abstrak
Penelitian ini bertujuan meningkatkan hasil belajar matematika siswa kelas VIII E SMP Negeri 2 Kota Bengkulu. Subjek dalam penelitian ini adalah seluruh siswa kelas VIII E SMP Negeri 2 Kota Bengkulu semester genap tahun ajaran 2016/2017. Penelitian ini dilaksanakan dalam tiga siklus yang terdiri dari: perencanaan, pelaksanaan tindakan, observasi, serta analisis dan refleksi. Pengumpulan data dilakukan dengan cara pengamatan atau observasi, dan pemberian tes pada setiap akhir siklus pembelajaran. Hasil penelitian menunjukkan bahwa terjadi peningkatan hasil belajar matematika siswa yang dapat dilihat dari nilai rata-rata hasil belajar siswa siklus I, siklus II dan siklus III secara berturut-turut adalah 72,3; 74,5; dan 79,5 serta ketuntasan belajar klasikal siklus I, siklus II dan siklus III secara berturut-turut adalah 47,22\%; 71,88\% dan 86,11\%. Peningkatan aktivitas belajar siswa dapat di lihat dari nilai hasil observasi aktivitas belajar matematika siswa siklus I, siklus II, dan siklus III secara berturut-turut adalah 16,5 (kriteria cukup), 23,8 (kriteria aktif) dan 26 (kriteria aktif).
\end{abstract}

Kata kunci: pembelajaran konstruktivisme, pendekatan pembelajaran, kemampuan pemecahan masalah

\begin{abstract}
This study aims to improve students' mathematics learning outcomes of grade VIII E SMP Negeri 2 Kota Bengkulu. Subjects in this study were all students of class VIII E SMP Negeri 2 Kota Bengkulu even semester of academic year 2016/2017. This research was conducted in three cycles consisting of: planning, action implementation, observation, and analysis and reflection. Data collection is done by observation or observation, and giving the test at the end of the learning cycle. The results showed that there is an increase in student learning outcomes mathematics can be seen from the average value of student learning outcomes cycle I, cycle II and cycle III in a row is 72.3; 74.5; And 79,5 and the completeness of classical learning cycle I, cycle II and cycle III in a row is 47.22\%; 71.88\% and $86.11 \%$. The increase of student learning activity can be seen from the observation result of student learning activity of cycle I, cycle II, and cycle III are 16,5 (enough criteria), 23,8 (active criterion) and 26 (active criteria) .
\end{abstract}

Keywords: constructivism, lesson approachment, solving problem

\section{PENDAHULUAN}

Setiap manusia membutuhkan pendidikan yang akan menjadi modal untuk hidupnya di masa depan. Pendidikan matematika diharapkan dapat menjadi wahana bagi peserta didik untuk mempelajari kemampuan dan potensi diri sendiri mengenai prospek pengembangan lebih lanjut dalam menerapkannya di dalam kehidupan seharihari. Matematika adalah pengetahuan tentang fakta dan hukum-hukum yang didasarkan atas perhitungan dan disusun dalam suatu sistem yang teratur. Tidak dapat dipungkiri bahwa matematika merupakan bagian yang tidak dapat terpisahkan dari kehidupan manusia. Sehingga hal ini lah yang menjadi alasan bahwa matematika menjadi sangat penting bagi semua orang.

Mengingat bahwa matematika itu penting, maka perlu diberikan pendidikan sejak dini. Bahkan sejak memasuki bangku sekolah seseorang telah dikenalkan dengan angkaangka, orang tuanya pun sudah mengajarkan membaca dan berhitung yang akan menjadi 
modal untuknya belajar disekolah. Di berbagai sekolah baik SD, SMP, maupun SMA pasti ada mata pelajaran matematika sebagai salah satu pembelajaran wajib untuk semua tingkatan kelas.

Berdasarkan pengalaman yang diperoleh peneliti pada saat melakukan observasi disekolah, mata pelajaran matematika ini kurang diminati oleh kebanyakan siswa-siswi dikarenakan mata pelajaran matematika di anggap sebagai mata pelajaran yang sulit. Hal ini menyebabkan aktivitas belajar matematika siswa menjadi rendah, sehingga hasil belajar siswa juga menjadi rendah. Hasil belajar adalah kemampuan-kemampuan yang dimiliki siswa setelah ia menerima pengalaman belajarnya (Sudjana, 2006:22). Setiap guru diwajibkan untuk dapat melakukan pendekatan yang akan membuat siswa menjadi aktif dalam belajar. Salah satu solusi yang dapat membantu siswa aktif dalam belajar adalah dengan menggunakan pendekatan pembelajaran yang tepat.

Pendekatan pembelajaran dapat berarti anutan pembelajaran yang berusaha meningkatkan kemampuan-kemampuan kognitif, afektif, dan psikomotorik siswa dalam pengolahan pesan sehingga tercapai sasaran belajar (Dimyati dan Mudjiono, 2013:185). Pendekatan pembelajaran jika dilihat dari pusat pembelajaran dibedakan menjadi teacher centered learning dan student centered learning (Wardoyo, 2013:28). Dalam kenyataannya pada pembelajaran matematika masih banyak guru yang memilih pendekatan pembelajaran yang terpusat pada guru. Pembelajaran yang terpusat pada guru harus dihindari karena tidak membantu siswa dalam pemecahan masalah. Akan lebih baik jika guru menerapkan pendekatan pembelajaran yang terpusat pada siswa agar siswa menjadi lebih aktif dalam belajar.

Pendekatan pembelajaran yang berorientasi konstruktivisme adalah suatu pendekatan yang tepat dilakukan oleh guru. Pembelajaran konstruktivisme adalah pembelajaran yang berkenaan dengan bagaimana anak memperoleh pengetahuan dalam berinteraksi dengan lingkungannya (Ansari, 2016:65). Dalam pelaksanaan pembelajaran matematika yang menggunakan pendekatan pembelajaran yang berorientasi konstruktivisme pengetahuan dikembangkan secara aktif oleh siswa dan siswa didorong untuk membangun pengetahuan mereka sendiri. Guru hadir membantu siswa belajar, serta mempersiapkan lingkungan yang memungkinkan siswa dapat memperoleh informasi melalui pengalaman-pengalaman belajar yang luas.

Menurut Wardoyo (2013:57), belajar dalam pandangan konstruktivisme adalah "mengkonstruksi" pengetahuan. Dalam pernyataan ini berarti bahwa, pengetahuan dikonstruksi dari proses pengintegrasian pengetahuan baru terhadap struktur kognitif yang sudah ada dan dilakukannya penyesuaian struktur kognitif dengan informasi baru yang didapatkan.

Teori pembelajaran konstruktivisme bisa dipahami sebagai teori tentang pembentukan makna (a meaning-making theory). Belajar disini merupakan proses mengkonstruksi pengetahuan baru. Dalam pembelajaran konstruktivisme, peran guru tidak hanya menjadi pemberi pengetahuan, melainkan guru berperan sebagai mediator, fasilitator dan rekan penjelajah yang mendorong pembelajar untuk bertanya, menantang dan memformulasikan gagasan, pendapat dan kesimpulan mereka sendiri. Guru dapat memberi kesempatan siswa untuk menemukan atau menerapkan ide-ide mereka sendiri, dan mengajar siswa menjadi sadar dan secara sadar menggunakan strategi mereka sendiri untuk belajar.

Pembelajaran yang menggunakan pendekatan konstruktivisme menuntut agar seorang pendidik mampu menciptakan pembelajaran sedemikian rupa sehingga peserta didik dapat terlibat secara aktif dengan materi pelajaran melalui interaksi sosial yang terjalin di dalam kelas (Wardoyo, 2013:28).

Pendekatan pembelajaran yang beorientasi konstruktivisme menerapkan pembelajaran kooperatif secara intensif, dimana dalam pembelajaran siswa akan lebih mudah menemukan dan memahami konsep-konsep yang sulit apabila mereka dapat saling mendiskusikan masalah-masalah itu dengan temannya. 
Dalam proses pembelajaran dikelas, penerapan pembelajaran konstruktivistik digambarkan dalam lima langkah pembelajaran sebagai berikut:

1. Pengaktifan pengetahuan yang sudah ada (activating knowledge).

2. Pemerolehan pengetahuan baru (acquiring knowledge).

3. Pemahaman pengetahuan (understanding knowledge).

4. Menerapkan pengetahuan dan pengalaman yang diperoleh (applying knowledge).

5. Melakukan refleksi (reflecting

on knowledge).

Menurut Trianto (2011:75) contoh aplikasi pendekatan konstruktivis dalam pembelajaran adalah siswa belajar bersama dalam kelompokkelompok kecil dan saling membantu satu sama lain. Kelas disusun dalam kelompok yang terdiri dari 4 atau 5 siswa, campuran siswa berkemampuan tinggi, sedang, dan rendah. Siswa tetap berada dalam kelompoknya selama beberapa minggu. Mereka diajarkan ketrampilan khusus agar dapat bekerja sama dengan baik didalam kelompoknya, selama kerja dengan kelompok, tugas anggota kelompok adalah mencapai ketuntasan materi yang ditugaskan guru dan saling mebantu teman sekelompok mencapai ketuntasan belajar. Pada saat siswa sedang bekerja dalam kelompok guru berkeliling memberikan pujian kepada kelompok yang sedang bekerja dengan baik, dan memberikan bimbingan kepada kelompok yang mengalami kesulitan.

Pada awal pembelajaran dengan menerapkan pendekatan pembelajaran yang berorientasi konstruktivisme siswa diberikan permasalahan yang telah diskenariokan oleh guru berdasarkan pada tujuan pembelajaran. Dalam skenario permasalahan, siswa mengidentifikasi fakta-fakta yang berkaitan dengan masalah dan kemudian membuat hipotesis. Langkah selanjutnya siswa menyelesaikan permasalahan yang dihadapinya dengan cara menerapkan atau mengaplikasikan pengetahuan baru yang mereka miliki sehingga menemukan jawaban. Setelah itu siswa membuat rangkuman atau kesimpulan dari hasil dan proses pembelajaran yang telah mereka lakukan.
Dari hasil wawancara kepada guru kelas VIII di SMP Negeri 2 kota Bengkulu diperoleh permasalahan bahwa siswa mengalami kesulitan dalam menyelesaikan soal-soal terutama pada materi bangun ruang, dan menyebabkan hasil belajar menjadi rendah. Sehingga perlu adanya upaya untuk meningkatkan hasil belajar matematika siswa. Penerapan pendekatan pembelajaran yang berorientasi konstruktivisme dapat membantu siswa untuk meningkatkan hasil belajar matematika siswa.

Berdasarkan latar belakang yang telah diuraikan dapat dirumuskan adanya permasalahan sebagai berikut :

1. Bagaimana meningkatkan aktivitas belajar matematika siswa dengan menerapkan pendekatan pembelajaran yang berorientasi konstruktivisme pada siswa kelas VIII di SMP Negeri 2 kota Bengkulu?

2. Bagaimana meningkatkan hasil belajar matematika siswa dengan menerapkan pendekatan pembelajaran yang berorientasi konstruktivisme pada siswa kelas VIII di SMP Negeri 2 kota Bengkulu?

Adapun tujuan penelitian tindakan kelas ini adalah :

1. Untuk meningkatkan aktivitas belajar matematika siswa melalui pendekatan pembelajaran yang berorientasi konstruktivisme pada siswa kelas VIII di SMP Negeri 2 kota Bengkulu.

2. Untuk meningkatkan hasil belajar matematika siswa melalui pendekatan pembelajaran yang berorientasi konstruktivisme pada siswa kelas VIII di SMP Negeri 2 kota Bengkulu.

\section{METODE}

Jenis penelitian dalam penelitian ini adalah penelitian tindakan kelas (Classroom Action Research). Dalam Penelitian Tindakan Kelas ini secara garis besar terdapat empat tahapan yang harus dilalui, yaitu: 1) Perencanaan, 2) Pelaksanaan, 3) Pengamatan, 4) Refleksi.

Instrumen yang digunakan dalam penelitian ini adalah lembar observasi aktivitas belajar siswa yang di isi oleh dua orang 
observer dan lembar tes siklus siswa yang dilakukan setiap akhir siklus. Pengisian lembar observasi aktivitas siswa berpedoman pada penskoran seperti yang tertera pada tabel berikut ini:

\section{Tabel 1. Pedoman Penskoran Pengamatan} Aktivitas Siswa

\begin{tabular}{|c|c|}
\hline Pilihan Jawaban & Skor \\
\hline Baik & 3 \\
\hline Cukup & 2 \\
\hline Kurang & 1 \\
\hline
\end{tabular}

(Mod. Dimyati \& Mudjiono (2013:125) dan Aqib, dkk (2014:67))

Rumus yang digunakan untuk menghitung rata-rata hasil penilaian lembar observasi aktivitas siswa yaitu:

$$
\text { rata }- \text { rata skor siklus } i=\frac{\text { jumlah skor siklus } i}{\text { banyaknyapertemuan }}
$$

Karena observasi dilakukan oleh dua orang observer maka, rata-rata skor lembar observasi keaktifan siswa diperoleh dengan rumus sebagai berikut:

rata - rata skor lembar observasi siklus $i$

Keterangan

$$
=\frac{\overline{x_{1}}+\overline{x_{2}}}{2}
$$

$\overline{x_{1}}=$ rata-rata skor siklus ke-i observer 1

$\overline{x_{2}}=$ rata-rata skor siklus ke-i observer 2

Jadi, skor rata-rata aktivitas siswa menjadi nilai kuantitatif dengan kategori penilaian yaitu pada tabel berikut:

Tabel 2. Kategori Penilaian aktivitas siswa

\begin{tabular}{|c|c|}
\hline $\begin{array}{c}\text { Kriteria } \\
\text { Penilaian }\end{array}$ & Kisaran Skor \\
\hline Kurang Aktif & $10 \leq x \leq 16$ \\
\hline Cukup Aktif & $16<x \leq 23$ \\
\hline Aktif & $23<x \leq 30$ \\
\hline
\end{tabular}

Berdasarkan hasil perhitungan jika hasil aktivitas siswa mencapai kriteria aktif yaitu berada pada interval $23<x \leq 30$, sehingga dapat disimpulkan bahwa aktivitas belajar siswa pada siklus tersebut meningkat.

Hasil belajar siswa dilihat dari nilai akhir setiap siswa yang diperoleh dari gabungan antara LKS dan tes akhir setiap siklus. Nilai maksimal untuk LKS dan Tes ini adalah 100. Analisis dilakukan dengan tahap pemberian nilai yang dicapai setiap siswa dengan rumus dari Arikunto (2005:278) yaitu:

$$
N A=\frac{\frac{\left(F_{1}+F_{2}+\cdots+F_{n)}\right.}{n}+2 S}{3}
$$

Keterangan:

NA $=$ Nilai akhir

$\mathrm{F}=$ Nilai tes formatif (LKS)

$\mathrm{S}=$ Nilai tes sumatif (Tes Siklus)

Menurut (Aqib, dkk., 2014: 41) pembelajaran matematika dikatakan berhasil dalam meningkatkan hasil belajar siswa jika memenuhi ketuntasan belajar minimal $75 \%$. Rumus yang digunakan untuk menghitung Persentase ketuntasan belajar klasikal $(P)$ yaitu:

$$
\mathrm{P}=\frac{\sum \text { siswa yang tuntas belajar }}{\sum \text { siswa }} \times 100 \%
$$

Aqib, dkk. (2014:205)

Siklus penelitian ini akan dihentikan jika kriteria keberhasilan tindakan telah tercapai. Adapun kriteria dan indikator keberhasilan tindakan adalah:

1. Aktivitas belajar siswa dalam pembelajaran pemecahan masalah matematika mencapai kriteria aktif yaitu berada pada interval $23<x \leq 30$.

2. Hasil belajar siswa dilihat dari rata-rata nilai akhir siswa yang diperoleh $\geq 75$ dan persentase ketuntasan belajar $75 \%$

\section{HASIL DAN PEMBAHASAN}

Penelitian tindakan kelas melalui Penerapan Pendekatan Pembelajaran yang Berorientasi Konstruktivisme untuk Meningkatkan Hasil Belajar Matematika Siswa 
Kelas VIII SMP Negeri 2 Kota Bengkulu dilaksanakan dalam 3 siklus.

Adapun hasil pengamatan disetiap aspek aktivitas siswa dapat dilihat pada tabel berikut:

Tabel 3. Perhitungan Aktivitas Siswa Tiap Aspek

\begin{tabular}{|c|c|c|c|c|c|c|}
\hline Aspek & $\begin{array}{c}\text { Siklus } \\
\text { I }\end{array}$ & ket & $\begin{array}{c}\text { Siklus } \\
\text { II }\end{array}$ & ket & $\begin{array}{c}\text { Siklus } \\
\text { III }\end{array}$ & ket \\
\hline 1 & 1.83 & $\mathrm{~K}$ & 2.33 & $\mathrm{C}$ & 3 & $\mathrm{~B}$ \\
\hline 2 & 2 & $\mathrm{C}$ & 2.5 & $\mathrm{C}$ & 3 & $\mathrm{~B}$ \\
\hline 3 & 1.83 & $\mathrm{~K}$ & 2.33 & $\mathrm{C}$ & 2.33 & $\mathrm{C}$ \\
\hline 4 & 1.33 & $\mathrm{~K}$ & 2 & $\mathrm{C}$ & 2 & $\mathrm{C}$ \\
\hline 5 & 1.33 & $\mathrm{~K}$ & 2.67 & $\mathrm{C}$ & 3 & $\mathrm{~B}$ \\
\hline 6 & 2 & $\mathrm{C}$ & 2.5 & $\mathrm{C}$ & 2.33 & $\mathrm{C}$ \\
\hline 7 & 2 & $\mathrm{C}$ & 2.5 & $\mathrm{C}$ & 3 & $\mathrm{~B}$ \\
\hline 8 & 1.5 & $\mathrm{~K}$ & 2.5 & $\mathrm{C}$ & 3 & $\mathrm{~B}$ \\
\hline 9 & 1 & $\mathrm{~K}$ & 2.17 & $\mathrm{C}$ & 2 & $\mathrm{C}$ \\
\hline 10 & 1.67 & $\mathrm{~K}$ & 2.33 & $\mathrm{C}$ & 2.33 & $\mathrm{C}$ \\
\hline
\end{tabular}

Tabel 3 memperlihatkan bahwa terjadi peningkatan pada masing-masing aspek. Aspek 1, 2, 5, 7, dan 8 selalu mengalami peningkatan disetiap siklusnya dan mencapai kategori baik pada siklus 3. Aspek 3, 4, 6, 9, dan 10 juga mengalami peningkatan namun hanya mencapai kategori cukup pada siklus 3 .

Secara keseluruhan hasil perhitungan pada lembar pengamatan untuk setiap siklusnya, aktivitas belajar mengalami peningkatan seperti terlihat pada tabel 3 berikut ini:

Tabel 4. Perhitungan Hasil Aktivitas Siswa

\begin{tabular}{|c|c|c|c|c|}
\hline Sikus & $\begin{array}{c}\text { Observer } \\
\text { I }\end{array}$ & $\begin{array}{c}\text { Observer } \\
\text { II }\end{array}$ & $\begin{array}{c}\text { Skor } \\
\text { Rata- } \\
\text { Rata }\end{array}$ & Kriteria \\
\hline I & 16 & 17 & 16,5 & Cukup \\
\hline II & 23,3 & 23,6 & 23,8 & Aktif \\
\hline III & 25,6 & 26,3 & 26 & Aktif \\
\hline
\end{tabular}

Tabel 4 memperlihatkan bahwa aktivitas belajar dalam penerapan pendekatan pembelajaran yang berorientasi konstruktivisme siklus I terletak pada kategori cukup dengan skor rata-rata aktivitas yang diperoleh yaitu 16,5 dan interval nilai $10 \leq$ $x \leq 16$. Hal tersebut terjadi karena siswa masih dalam proses beradaptasi dengan pendekatan pembelajaran yang baru.

Pada siklus II aktivitas belajar siswa berada pada kategori aktif dengan skor rata-rata aktivitas yang diperoleh yaitu 23,8 dan interval nilai $16 \leq x \leq 23$.

Sedangkan pada siklus III aktivitas belajar siswa mencapai dalam kategori aktif dengan skor rata-rata aktivitas yang diperoleh yaitu 26 dan interval nilai $23 \leq x \leq 30$.

Hasil belajar siswa dinilai melalui gabungan antara nilai LKS dan Tes yang dilakukan setiap akhir siklus I, siklus II, dan siklus III. Berikut ini adalah rekapitulasi hasil perhitungan nilai akhir yang diperoleh siswa setiap siklusnya:

Tabel 5. Hasil Belajar Siswa Setiap Siklus

\begin{tabular}{|c|c|c|}
\hline Siklus & $\begin{array}{c}\text { Nilai rata- } \\
\text { rata }\end{array}$ & $\begin{array}{c}\text { Ketuntasan } \\
\text { belajar klasikal }\end{array}$ \\
\hline I & 72,3 & $47,2 \%$ \\
\hline II & 74,5 & $72 \%$ \\
\hline III & 79,5 & $86 \%$ \\
\hline
\end{tabular}

Berdasarkan tabel 5, pada siklus I hasil belajar siswa yang masih rendah. Setelah guru mengamati hasil belajar yang diperoleh siswa, siswa yang mencapai KKM adalah 17 orang dan yang tidak mencapai KKM yaitu sebanyak 19 orang. Hal ini terjadi karena masih banyak siswa yang bermain-main dan mengganggu teman saat belajar dan berdiskusi. Sehingga pada siklus I hanya mencapai rata-rata nilai 72,3 dan ketuntasan belajar klasikal sebesar $47,2 \%$.

Pada siklus II, hasil belajar siswa mengalami peningkatan baik secara klasikal maupun rata-rata nilai siswa. Siswa mulai serius dalam belajar dan berdiskusi. Berdasarkan hasil pengamatan terhadap jawaban Tes siswa sudah dapat menjawab soal namun siswa masih kesulitan dalam menghitung nilai yang akan dicari. Hal ini menyebabkan jawaban yang diperoleh siswa masih ada yang salah. Sehingga pada siklus II rata-rata nilai mencapai 74,9 dan ketuntasan belajar klasikal sebesar $72 \%$.

Pada siklus III, siswa terbiasa dengan LKS yang diberikan. Siswa dapat berdiskusi dengan baik, dan hasil perhitungan siswa juga sudah benar. Tindakan ini terbukti dengan peningkatan nilai rata-rata siswa 79,5 dan ketuntasan belajar klasikal siswa menjadi $86 \%$. 
Oleh sebab itu penelitian dihentikan pada siklus III.

Peningkatan juga terjadi pada nilai setiap individu siswa setiap siklusnya. Siswa yang mempunyai nilai yang selalu meningkat dikarenakan rata-rata siswa tersebut selalu mengikuti setiap proses pembelajaran dengan bersungguh-sunguh dan selalu hadir dalam kegiatan pembelajaran di kelas. Berdasarkan nilai tes hasil belajar siswa pada setiap siklus, perkembangan nilai hasil belajar siswa sangat beragam, hal tersebut dapat dilihat pada grafik berikut ini:

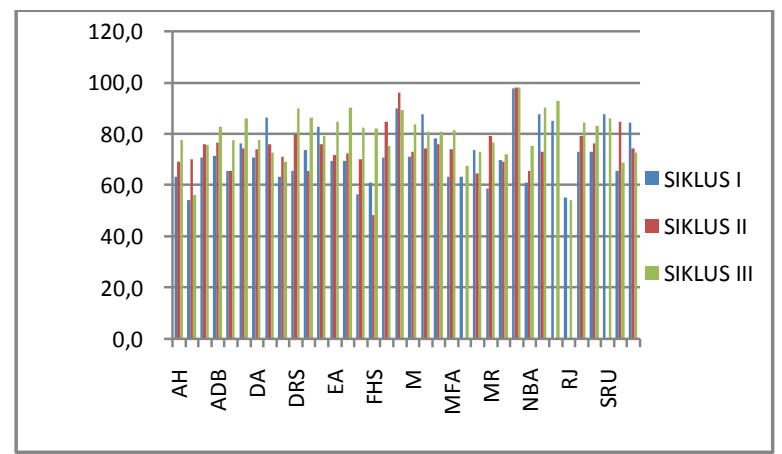

Gambar 1. Perkembangan Hasil Belajar Siswa pada setiap Tes Siklus

Dari gambar diatas, dapat dilihat bahwa perkembangan nilai tes hasil belajar siswa tidak selalu meningkat pada setiap siklusnya. Jumlah siswa yang nilai tes hasil belajarnya selalu mengalami peningkatan pada sertiap siklusnya adalah 17 siswa. Sedangkan siswa lainnya meningkat lalu menurun pada setiap siklus dan sebaliknya.

Hasil pengamatan peneliti terhadap nilai tes hasil belajar siswa setiap siklusnya, terdapat 1 orang siswa yang tidak pernah mencapai nilai $\geq 71$ yang merupakan kriteria ketuntasan minimal (KKM). Ada beberapa faktor siswa tersebut tidak pernah mencapai nilai KKM seperti kurangnya persiapan diri menjelang pelaksanaan tes siklus, jarang masuk pada saat jam pelajaran matematika, tidak mau bertanya saat merasa kesulitan, jarang ikut dalam diskusi kelompok, dan tidak memperhatikan penjelasan guru. Namun secara umum, hasil belajar siswa kelas VIII E mengalami peningkatan kentutasan belajar pada siklus III.
Berdasarkan hasil penelitian dan pembahasan, dapat di ambil kesimpulan sebagai berikut:

1. Penerapan pendekatan pembelajaran yang berorientasi konstruktivisme di kelas VIII E SMP Negeri 2 Kota Bengkulu dapat meningkatkan hasil belajar siswa dengan cara:

a. Siswa diberi kesempatan untuk membangun pengetahuannya sendiri berdasarkan informasi-informasi yang diberikan oleh guru.

b. Guru membentuk kelompok belajar yang heterogen berdasarkan hasil belajar dan prilaku siswa agar dapat meningkatkan keefektifan kegiatan diskusi kelompok.

c. Guru memberikan kesempatan kepada siswa untuk berpendapat dan menyebutkan pengetahuan yang dimilikinya.

d. Guru membimbing siswa serta memberikan motivasi kepada siswa yang berkemampuan rendah dan kurang aktif.

e. Guru melakukan pendekatan dan memberikan perhatian kepada siswa yang tidak tertib agar mau mengikuti tahap pembelajaran dengan baik.

f. Guru memberikan teguran kepada siswa yang ribut, dan memisahkan siswa yang sering ribut agar tidak duduk berdekatan.

Ini didukung oleh skor aktivitas siswa pada siklus I dengan rata-rata skor 16,5 masih tergolong aktivitas nya cukup aktif, siklus II meningkat pada kriteria aktivitas nya aktif dengan rata-rata skor 23,8 dan untuk siklus III aktivitas siswa tergolong kriteria aktif dengan skor rata-rata 26. Dan hasil belajar siswa dinyatakan dengan adanya peningkatan nilai rata-rata dan ketuntasan belajar siswa pada setiap siklus. Nilai rata-rata siswa 72,3 pada siklus I meningkat menjadi 74,5 pada siklus II. Pada siklus III meningkat hingga mencapai 79,5. Sedangkan ketuntasan belajar siswa pada siklus I sebesar 47,22\%, meningkat menjadi $71,88 \%$ pada siklus II, dan terus meningkat hingga mencapai $86,11 \%$ pada siklus III. 


\section{SARAN}

Berdasarkan penelitian yang telah dilakukan maka peneliti memberikan beberapa saran, yaitu:

1. Penerapan pendekatan pembelajaran yang berorientasi konstruktivisme diterapkan dalam kelompok belajar kecil yang dibentuk secara bertahap dengan desain refleksi terhadap pembelajaran sebelumnya

2. Dalam proses pembelajaran hendaknya guru dapat memberikan variasi dan disesuaikan dengan karakteristik siswa dengan lebih memperhatikan materi yang akan diajarkan.

\section{DAFTAR PUSTAKA}

Ansari, B. I. (2016). Komunikasi Matematik Strategi Berfikir dan Manajemen Belajar Konsep dan Aplikasi. Banda Aceh: PeNA.

Aqib, Z., dkk. Penelitian Tindakan Kelas untuk Guru SD, SLB dan TK. Bandung:

Yrama Widya.

Arikunto, Suharsimi. (2005). Dasar-dasar Evaluasi Pendidikan. Jakarta: Bumi Aksara.

Dimyati, \& Murdjiono. 2010. Belajar dan Pembelajaran. Jakarta: Rineka Cipta.

Sudjana, Nana. (2006). Penilaian Hasil Proses Belajar Mengajar. Bandung: PT Rosda Karya

Trianto. (2011). Model-model pembelajaran inovatif berorientasi konstruktivistik. Jakarta: Prestasi Pustakaraya.

Wardoyo, S. M. (2013). Pembelajaran Konstruktivisme, Teori Dan Aplikasi Pembelajaran Dalam Pembentukan Karakter. Bandung: Alfabet. 